\section{Cooperative relationships and competitiveness in supermarket sector}

\author{
Andressa Centenaro \\ Claudionor Guedes Laimer \\ Faculty Meridional (IMED), IMED Business School, Passo Fundo, RS, Brazil
}

\begin{abstract}
Purpose - This article aims to investigate the influence of cooperative relations in the performance of companies in the supermarket sector, comparing the companies associated networks with companies not associated.
\end{abstract}

Design/methodology/approach - The research method employed was a survey research with 31 companies.

Findings - The results indicate that the cooperative relationships with suppliers have a positive impact on companies of performance, while the cooperative relationships with competitors and local institutions do not influence the performance. Moreover, it appears that there is no relationship between participation in a network of cooperation and achieving superior performance. However, companies linked to the network present better cooperative relationships with suppliers, which positively impacts the performance and therefore have competitive advantages over companies not associated to networks.

Originality/value - The cooperative relationships with suppliers can provide benefits such as reducing logistics costs, improved product portfolio, better negotiating prices and terms, partnership for conducting marketing strategies among others, thus increasing the competitiveness of companies in the supermarket sector.

Keywords - Inter-organizational networks. Cooperation networks. Cooperative relationships. Competitiveness. Performance.
Received on

03/13/2016

Approved on

$09 / 16 / 2016$

\section{Responsible editor:}

Prof. Dr. João Maurício Gama

Boaventura

\section{Evaluation process:}

Double Blind Review 


\section{Introduction}

Organizations are inserted in an economic environment increasingly marked by rapid change and great technological and information revolution (Castells, 1999; Olave \& Amato, 2005), which has forced companies to seek new strategies to remain competitive (Olave \& Amato, 2005; Bueno \& Balestrin, 2012; Keupp, Palmie, \& Gassmann, 2012). Under these conditions, the cooperative relationships offer the possibility of cost and risk sharing, and keep up to date with the knowledge constantly renewed, emerging as well as new strategic alternative for companies.

One of the central arguments that cooperative relationships are a strategic alternative for companies is rooted in the logic that the organizations' performance began not to rely on the resources and internal capabilities of companies, but also on the relationships and resource flows the company has with other companies and other organizations (Dyer \& Singh, 1998; Ahuja, 2000; Bizzi \& Langley, 2012). Thus, it is important to investigate the inter-organizational relationships, considering that they may affect the financial performance and/or non-financial companies (Keupp et al., 2012; Santos, Kalsing, \& Hansen, 2014; Dagnino, Levanti, \& Picone, 2015). Therefore, it is of interest to this study to investigate the influence of cooperative relationships in the financial companies' performance.

In this sense, a company can form a cooperative relationship with suppliers, customers, government organizations, educational and research institutions and even with other companies in the same segment (Olave \& Amato, 2005; Balestrin \& Verschoore, 2016). In these relationships, companies have control over their resources; however, they decide to use them in conjunction with other organizations (Ebers, 1997). In addition, the cooperative relationships are connected to the sharing of information between companies, for joint actions and the intensity of interpersonal relations (Vieira, Yoshizaki, \& Ho, 2009).
An example of how cooperative relationships have been used as a strategic alternative is in the supermarket sector. The economic transformations through which Brazil has passed since the 1990s, where the currency stabilization through the Real Plan, put the companies in a new competitive environment of increased competition (Lima, Maia, Sproesser, Moraes, \& Moraes, 2006). In this context, there have been several mergers and acquisitions of large supermarkets, with the formation of large retailers that invest heavily in maximizing operational efficiency and marketing (Lima et al., 2006; Laimer \& Laimer, 2009; Gaspar, Borgato, \& Lima, 2013). Due to the fact that small and medium enterprises in the supermarket sector in general have no technical and financial resources to carry out such investments, they lose competitiveness (Lima et al., 2006). Also, due to not having a comparable operational scale to the major retailers and not the same bargaining power, they face difficulties with suppliers to obtain competitive prices (Gaspar et al., 2013).

Thus, due to the high existing competition in the supermarket sector, small and mediumsized supermarkets, known as neighborhood supermarkets realized the need to establish cooperative relationships with each other, thus creating cooperation networks (Laimer \& Laimer, 2009; Gaspar et al., 2013). These cooperation networks are inter-organizational relationships established between companies in the same segment, to increase competitiveness (Marcon $\&$ Moinet, 2001; Balestrin \& Vargas, 2004).

In this sense, cooperation networks represent an alternative for companies of small and medium-sized of supermarket sector, in order to achieve competitive gains such as economies of scale, increased product portfolio, better negotiating prices and terms with suppliers and implementation of marketing strategies (Lima et al., 2006). This study aims to verify the influence of cooperative relationships in the performance of supermarket sector companies in the northwestern region of Rio Grande do Sul state, comparing the 
companies connected to networks with companies not associated to networks. Therefore, according to the Brazilian Association of Supermarkets (Abras) (2014) it is estimated that in Brazil there are 3,950 supermarkets associated with over 130 cooperation networks, pointing to new standards of competitiveness in the Brazilian supermarket sector.

The article is structured with this introduction and four chapters. The theoretical framework is found in chapter two with the theoretical discussion of the cooperation networks and the competitiveness of enterprises. Chapter three presents the research method with the description of the methodological procedures observed in the survey. The results and discussion are presented in chapter four, explaining the empirical evidence through the theoretical foundations. Finally, chapter five presents the conclusions of the study, with contributions, limitations and suggestions for future research.

\section{Theoretical Framework}

The theoretical framework summarizes the theoretical discussions about the competitiveness of enterprises and their cooperative relationships, consolidating the chapter regarding the relations between cooperative relationships and competitiveness.

\section{I Competitiveness}

Competitiveness can be explained as the company's ability to formulate and implement strategies to enhance or maintain a sustainable position in its market (Ferraz, Kupfer, \& Haguenauer, 1996). Thus, competitiveness is related to the company's ability to compete in the market and get superior performance to the competitors.

Moreover, a company's competitiveness can be identified by four features: dynamic with the ability to transform potential into results; competitive with the ability to control resources and capabilities, aiming at superior performance; oriented and long-term; relative, and compared with other companies in the industry to check their level of competitiveness (Man, Lau, \& Chan, 2002).

In this sense, competitiveness can be determined by competitive environment, or by competitive forces, which are seen as the determinants of the sector and the company's competitiveness (Porter, 1991). Therefore, competitiveness is related to a number of factors in a given market, which is part of the interdependence between companies (Ferraz et al., 1996).

The concept of competitiveness also refers to the characteristics of the companies and is related to performance (Coutinho and Ferraz, 1994). Likewise, a competitive factor (e.g., cooperative relationships) becomes a competitive advantage for a company (Zaccarelli, 2006), which is measured by their performance. In other words, competitiveness can be understood as the ability to create and sustain superior performance relative to competitors.

The association of companies promotes competitiveness (Olave \& Amato, 2005; Caldeira, Durão, Pizzol, Pizzol, \& Brazil, 2015), evaluating the companies' performance (Dalcol, Siluk, Neuenfeldt, \& Soliman, 2014). Thus, the performance indicators are the result of accumulated skills and competitive strategies adopted by companies, due to the competitive environment in which they operate (Coutinho \& Ferraz, 1994).

Even though, company competitiveness may be translated in its ability to compete, it is essential to relate the competitiveness to the company's performance. Accordingly, Haguenauer (2012) associates the competitiveness to performance, which in the same way that the competitiveness involves a number of factors: the performance can be measured in several ways, such as the result of productivity, profitability and the value obtained in sales.

Although the performance can be measured in several ways, the literature contains two main approaches, financial performance and 
non-financial performance (Kaplan \& Norton, 1997). In this study we intend to investigate possible differences in the financial performance of companies by virtue of cooperative relationships. Thus appropriating the concept of performance described by Haguenauer (2012), is to say that the performance of companies may result from the variation of revenue achieved in a given period. Thus, it was decided to use the revenue (value obtained in sales) as a metric of the companies' performance (Wegner, Agnes, Callado, \& Callado, 2016).

Therefore, the cooperative relationships can provide an increase in the companies' competitiveness and, as a consequence, differ in performance of the companies in relation to those companies which do not cooperate with others. So it presupposes that cooperative relationships are considered a determining factor of companies' competitiveness, enabling the company to engage in cooperation a superior performance in relation to its competitors that operate in isolation.

\subsection{Cooperative relationships}

Cooperative relationships have been formalized, especially through cooperation networks, also known as inter-organizational networks, which consist of a group of interconnected organizations by well-defined relationships, which can be in the same sector or be located along a production chain (Balestrin \& Arbage, 2007). According to Marcon and Moinet (2001), inter-organizational networks can be structured in four dimensions:

a) vertical dimension or hierarchy: these are the companies in the network, the array type and branch;

b) horizontal dimension or cooperation: consists of companies doing some kind of activity together through the cooperation of their members;

c) formal dimension or contractual: the coordination of the activities of the network structure is marked by the formal contract; d) informal dimension or connivance: the coordination of activities structure is marked by connivance and social rules, the complicity between the actors represented by the relations of friendship, affinity and kinship, such as those that occur in associations, clubs, and networks of friends.

Thus, the networks that are established by the association of several companies in the supermarket sector can be defined as a cooperation network. These networks, involving companies in the same industry or competitors, are marked by interdependence of complementary systems, such as production, research and the search for common goals (Ferreira \& Teixeira, 2008).

The factors that influence the formation and maintenance of cooperation networks are an issue of interest in various organizational studies. In this sense, Oliver (1990) reviews the literature and establishes some determinants contingencies forming relationships between organizations such as the need and efficiency.

The need is due to the scarcity of tangible or intangible assets, or when the organization needs external resources and then establishes bonds or exchanges with other organizations to achieve these features (Oliver, 1990). Whereas the efficiency motivates the organization to establish relationships in order to increase returns and reduce costs (Oliver, 1990).

The networks are characterized by the existence of autonomy in relation to external forces, as well as the presence of a certain degree of self-organization and an endogenous processing capacity, giving them an essentially dynamic character (Britto, 2002). In this regard, several studies (Balestrin \& Vargas, 2004; Wegner, Wittmann, \& Dotto, 2006; Balestrin \& Verschoore, 2010; Bulgacov, Arrebola, \& Gomel, 2012) have highlighted the importance of cooperation networks as strategic and organizational configuration which contributes to the companies' performance.

Thus, companies associated with a network can have facilitated access to various benefits such 
as exchange of information, knowledge, skills and other strategic resources, in addition to advantages such as reducing input costs through collective purchasing, decreased time development of new products, increasing the scope of the market through joint distribution, reduced storage and transport costs of inputs, among others (Balestrin \& Verschoore, 2016).

\subsection{Cooperative relationships and competitiveness}

Cooperative relationships are housed in an area of research called inter-organizational relationships, expression whose acronym is RIO (Cropper, Ebers, Huxham, \& Ring, 2008). As Cropper et al. (2008) published in the book 'The Oxford Handbook of Inter-Organizational Relations'; several terms are commonly used with the intention to designate the same relationships, such as: cooperation, collaboration, joint work, partnership, strategic alliance, association, among others.

In this sense, the literature mentions some properties of cooperative relationships. Among them, the cooperative relationships are a specific form of relational exchanges based on common goals, requiring high level of collaboration and determination, and is characterized by the creation of common processes or the joint activities (Vieira et al., 2009; Balestrin, Verschoore, \& Reyes, 2010).

The joint activities indicate the degree to which companies work together to seek common individual goals (Vieira et al., 2009). For Heide and John (1990), the actions and/or joint activities ensure that partners are focused on a continuous cooperation process, leaving aside possible opportunistic behavior.

Balestrin et al. (2010, p.462) states that the cooperative relationships "have the ability to facilitate the implementation of joint actions and resource transaction to achieve organizational goals". Thus, the understanding on how cooperative relationships can contribute to the companies' performance can be understood from the theoretical approach of the ResourceBased View (Gulati, 1999; Balestrin \& Verschoore, 2016).

In the theoretical approach of the Resource-Based View, a strategic resource is all assets, capacity, company attribute, information, knowledge, etc., which controlled by a company, allows it to devise and put in place strategies to improve their competitiveness (Barney, 1991). In this sense, using this theoretical approach, we assume that the company can use the relationships with other organizations to access and develop strategic resources, which could not be developed if it acted in isolation (Dyer \& Singh, 1998; Gulati, 1999; Ahuja 2000; Balestrin \& Verschoore, 2016).

Regarding the role of cooperative relationships on competitiveness, relationships between companies can provide two types of specific benefits: complementary resources and knowledge sharing (Ahuja, 2000). In this sense, the benefit of resource complementarities allows companies to combine their knowledge, skills and physical assets. But the sharing of knowledge refers to how the cooperative relationships can serve as information channels whereby technical advances and new approaches to solving problems flow from one company to another (Ahuja, 2000).

Hennart (2008, p.306) states that "in any society, there are potential gains from trading and shares". The change is related to obtaining comparative advantage and allows individuals to focus their activities on what they can do more efficiently, while shared work allows reaching a production scale that could not be achieved individually by a particular company (Hennart, 2008).

Vieira et al. (2009) identified that the cooperative relationships or collaborative, refers to the sharing of costs, risks and benefits. Specifically in the retail chain, the benefits of cooperative relationships can be described as: sharing delivery costs; sharing of costs from product returns, sharing logistical gains, and cost sharing to identify causes of inventory 
issues. Thus, collaboration is closely related to the way companies share information, jointly perform actions and enhance their interpersonal relationships (Vieira et al., 2009).

Zeng, Xie and Tam (2010), in turn, verified that small and medium-sized enterprises can be used in different forms of cooperation to gain access to knowledge and other external resources. Companies can establish cooperative relationships with competitors, with government organizations and teaching and research institutions (Zeng et al., 2010).

Lee, Park, Ryu and Baik (2010) simulated the long-term behavior of firms that have strategic alliances compared to the behavior of firms that do not. Thus, they found that in the long-term, companies form alliances to gain access to assets or complementary resources from their partners have better results than companies that operate individually. In addition, they also found that the greater the synergy of resources and capabilities between firms, the greater their competitiveness, and hence their performance.

Bulgacov et al. (2012) conducted a case study in a community of technologybased companies and revealed that at this condo one of the determinants of companies competitiveness is the existence of an environment and relationships of collaborative alliances in the use of strategic resources. According to the authors, the interviewed entrepreneurs stressed that their companies are most benefited in their competitive capabilities through shared resources, than affected by the possibly existing internal competition.

In this context, it may be noted that cooperative relationships with companies of the same segment or competitors are considered an important way of improving performance. Thus, the following research hypothesis is formulated:

H1: The cooperative relationships with competitors positively influence the performance of supermarket companies.
In addition, some studies focus on cooperation with suppliers for improving the company's performance, and suggest that cooperation with suppliers enables companies to improve productivity and risk reduction in the development of products and services, while reinforcing flexibility, product quality and adaptability to the market (Chung \& Kim, 2003; Vieira et al., 2009). Another benefit is that suppliers are important sources of information and knowledge for development and improvement of products and services (Zeng et al., 2010). Thus, the following research hypothesis was formulated:

H2: The cooperative relationships with suppliers positively influence the performance of supermarket companies.

Another important evidenced cooperative relationship in the literature is the relationship with local institutions, such as associations, trade unions, teaching and research institutions, government and financial organizations (Cropper et al., 2008). These institutions can be used for access to financial resources, technology and knowledge (Doloreux, 2004; Nieto \& Santamaria, 2007; Zeng et al., 2010). Thus, the following research hypothesis is proposed:

H3: The cooperative relationships with local institutions positively influence the performance of supermarket companies.

On the other hand, considering the evidence that there are differences between companies associated with networks and companies not associated to networks, the following research hypotheses is formulated:

H4: Companies associated with networks have a better performance than the nonassociated companies.

H5a: The cooperative relationships with competitors are larger in companies associated with a network. 
H5b: The cooperative relationships with suppliers are higher in companies associated with a network.

H5c: The cooperative relationships with local institutions are higher in companies associated with a network.

\section{Method}

The methodological procedures of the study are based on quantitative research with data collection strategy through a survey with a structured questionnaire. This type of research aims to describe the particular population characteristics or a certain phenomenon, or the establishment of associations between variables (Richardson, 1999).

\section{I Population and sample}

The study population comprises companies from the supermarket sector in the Northwest region of the state of Rio Grande do Sul. In this way, the population comprises commercial establishments with or without self-service and sale mainly of various food products, with a sales area of less than 5000 square meters, classified (Brazilian Institute of Geography and Statistics [IBGE], 2015) in:

a) Minimarkets, Grocery Stores and Warehouses (CNAE 4712-1/00): the activities of commercial establishments without self-service and with predominant sale of various food products, with sales area less than $300 \mathrm{~m}^{2}$;

b) Supermarkets (CNAE 4711-3/02): the activities of commercial establishments with predominant sale of various food products which also offer a wide range of other goods, sales area from 300 to $5,000 \mathrm{~m}^{2}$.

On the other hand, limitations on the precise quantification of the population to be surveyed are found due to lack of statistical information on the number of the supermarket sector companies (Laimer, 2007). Thus, the sample definition of the survey was selected by convenience where out of 40 typical companies in the supermarket sector, 31 companies agreed to participate. This type of sampling technique is characterized as non-probabilistic, i.e., a non-random sampling, which considers the participants according to their accessibility and availability to participate in it, because of the difficulty in obtaining a complete list of the target population study (Laimer, 2007).

\subsection{Data Collection}

Data collection was conducted through a structured questionnaire, which was based on validated scales by Laimer (2008), through factor analysis technique. The structured questionnaire was prepared in two blocks, the first block containing open questions in order to characterize the company, and the second block containing closed questions, in the form of statements in order to verify the relationship between the variables (Table 1).

The closed questions that measure the independent variables were measured by a Likert scale (enlarged) of 7 points, ranging from 1 (strongly disagree) to 7 (strongly agree). On the other hand, the closed question measuring the dependent variable was measured by a Likert scale (reduced) of 3 points, ranging from 1 (decreased), 2 (remained constant) and 3 (increased).

The questionnaire pretest was carried out by applying it to five companies of the population, and the adequacy and understanding of the questions/affirmative to the respondents was checked. As there was no change in the questionnaire after the pretest, the pretest respondents were considered in the sample. After concluding the pretest, the data collection phase began, when the questionnaire was applied by the researchers in person.

The questionnaire was carried out during the month of June 2015, visiting the companies surveyed. The respondents were company managers who were in positions of directors, managers or coordinators. Thus, the data 
collection procedure began with the presentation of information on the correct completion of the questionnaire and then the respondents were asked to individually complete the questionnaire, according to their perception of the reality of the company.

Table 1

Operationalization of the study variables

\begin{tabular}{|c|c|c|c|}
\hline Variable & Description of questions & Item & Type of question \\
\hline \multirow{2}{*}{$\begin{array}{l}\text { Company } \\
\text { characterization }\end{array}$} & $\begin{array}{l}\text { What is the store's sales areas? } \\
\text { What is the annual revenue of the store? }\end{array}$ & 2 & Open \\
\hline & Is the company associated with a network? & 1 & Dichotomous \\
\hline $\begin{array}{l}\text { Relationship with } \\
\text { competitors }\end{array}$ & $\begin{array}{l}\text { The company carries joint purchases with other supermarket companies. } \\
\text { The company carries joint promotions with other supermarket companies. } \\
\text { The company carries hiring and training in conjunction with other } \\
\text { supermarket companies. } \\
\text { The company has formal agreements with other supermarket companies to } \\
\text { buy, promotion, hiring and training. } \\
\text { Is it easy to establish "personal" social relations with the supermarket } \\
\text { companies' owners (festive events, sports, etc.)? } \\
\text { There is information exchange between supermarket companies about } \\
\text { customers, products, machinery, equipment, furniture and facilities. } \\
\text { The company participates in meetings and encounters with other supermarket } \\
\text { companies (associations, trade unions, central purchasing, etc.). }\end{array}$ & 7 & 7-point scale \\
\hline
\end{tabular}

The company makes purchases from suppliers, decides to purchase terms (price, term, discount, quantity, etc.).

The company carries joint promotions with suppliers (promotional discount, advertising, etc.).

The company carries out joint promotions with suppliers, decides how the

Relationship with promotion will be (promotional discount, advertising, etc.).

suppliers The company uses personal suppliers for aftermarket products in the store.

The company uses personal suppliers for aftermarket products in the store,

$7 \quad$ 7-point scale decides how to work.

The company has formal agreements with suppliers for purchases, promotions and replacement products.

The company uses suppliers' information and knowledge about clients, products, equipment and facilities.

The company uses the services provided by the Union (courses, advisory services, etc.).

The company uses the services provided by Trade Association (courses, advisory services, trade missions, fairs, etc.).

The company uses the services provided by government institutions

Relationship with (consultancies, economic incentives, fairs, etc.).

local institutions The company uses the services provided by educational institutions (courses,

$6 \quad 7$-point scale advisory services, consulting, technical visits, etc.).

The company uses the services provided by financial institutions such as:

financing, bonds discount, collection and cards agreements.

Local institutions provide information and knowledge about customers and products.

\begin{tabular}{lllll}
\hline Performance & Revenue of the store in the last five years. & 1 & 3 -point scale \\
\hline
\end{tabular}

Source: Adapted from “Construção de métricas para análise de redes de empresas”, by C. G. Laimer, 2008.

\subsection{Data analysis}

The collected data was tabulated and submitted to statistical analysis with the SPSS Statistic program, Version 21. Thus, the normality of the data was initially verified by analyzing the asymmetry and kurtosis values (Table 2). This verification aims at knowing if the data distribution corresponds to a normal distribution (Hair, Black, Babin, Anderson, \& Tatham, 2009). 
Table 2

The asymmetry and kurtosis analysis $(n=31)$

\begin{tabular}{lll}
\hline Variable & Asymmetry & Kurtosis \\
\hline Relationship with competitors & 0.372 & -1.412 \\
Relationship with suppliers & -0.332 & -0.681 \\
$\begin{array}{l}\text { Relationship with local } \\
\text { institutions }\end{array}$ & 0.198 & -1.007 \\
\hline
\end{tabular}

In the analysis of skewness and kurtosis indicators it is verified that the data meets the assumptions of normality, fulfilling the requirements for applying parametric tests (Hair et al., 2005). Therefore, regarding the verification of data distribution, asymmetric data is considered highly as the values greater than +1.00 or less than -1.00 , whereas for the kurtosis, out of the normal data distribution is considered as the values superior to +3.00 or less than -3.00 (Hair et al., 2009).

Thus, as it can be seen in Table 2, all variables meet the assumptions of normality indicated by Hair et al. (2009). Furthermore, the analysis was carried out on the basis of descriptive statistics for all variables, using the mean and standard deviation.

The reliability test was carried out through the analysis of Cronbach's Alpha, which showed acceptable coefficients greater than 0.600 (Malhotra, 2012). Similarly, the Pearson correlation test was carried out to allow multivariate analysis of data, such as multiple linear regression. Thus, the existence of multicollinearity was found, which indicated adequate correlations for the realization of multiple linear regression, or correlations less than 0.800 (Hair et al., 2009).

Thus, the multiple linear regression analysis was carried out. Multiple linear regression is the appropriate analysis method for analyzing the relationship between a single dependent variable/criteria and several independent variables/predictors (Hair, Babin, Money, \& Samouel, 2005). The dependent variable/criteria is characterized through performance, which was measured by the evolution of revenues, whereas the independent/predictor variables are characterized through the relationship with competitors, relationship with suppliers and relationship with local institutions. In addition, the independent and dependent variables used in the regression models were obtained through the average response in questions that make up each of the variables.

The last phase of the data analysis was to verify the existence of differences between the companies associated with networks and companies not associated to networks using the Student t-test and chi-square test. The t-test was used to verify the existence of differences in variables' relationship with competitors, relationship with suppliers and relationship with local institutions, while the chi-square test was used to verify the existence of differences in variable performance.

\section{Results and discussion}

This chapter presents the results and discussions based on the theoretical framework of the study, being organized with the characterization of the sample and the analysis and interpretation of data.

\section{I Characterization of the sample}

The sample of this study consists of 31 companies in the supermarket sector, 13 associated with the cooperation networks (41.9\%) and 18 not associated with any cooperation network (58.9\%). In terms of size, it appears that 17 companies are minimarkets, grocery stores and warehouses $(54.8 \%)$ and 14 companies are supermarkets $(45.2 \%)$. In addition, six companies have annual gross revenues of less than $\mathrm{R} \$ 120,000.00$ (19.4\%), 15 companies have between $\mathrm{R} \$ 120,000.00$ to $\mathrm{R} \$ 1,200,000.00$ $(48.4 \%)$ and 10 companies have revenues exceeding $\mathrm{R} \$ 1,200,000.00$ (32.3\%).

\subsection{Analysis and interpretation of data}

To test the influence of the relationship with competitors, relationship with suppliers and relationship with local institutions in the 
performance of companies multiple linear regression analysis was carried out (Table 3 ). Thus, it can be seen in Table 3 that the proposed regression model is significant $(\mathrm{p}<0.05)$ and has a coefficient of determination (R2) of 0.646 , indicating that $64.6 \%$ of the variation in performance results of the surveyed companies can be explained by the model.

Table 3

\section{Study Regression Model}

\begin{tabular}{|c|c|c|}
\hline Model & $\mathbf{R}^{2}$ & $\mathbf{F}$ \\
\hline $\begin{array}{l}\text { Performance }=\alpha+\beta_{1} \text { Relationship with } \\
\text { competitors }+\beta_{2} \text { Relationship with } \\
\text { suppliers }+\beta_{3} \text { Relationship with local } \\
\text { institutions }+\epsilon\end{array}$ & 0.646 & 6.445 \\
\hline
\end{tabular}

In Table 4, the coefficients of the independent variables of the proposed regression model and its significance are observed.

\section{Table 4}

\section{Summary of the results of the regression} analysis

\begin{tabular}{lccc}
\hline $\begin{array}{l}\text { Independent } \\
\text { variables }\end{array}$ & $\begin{array}{c}\text { Coefficient } \\
\beta\end{array}$ & $\mathbf{T}$ & Significance \\
\hline $\begin{array}{l}\text { Relationship with } \\
\text { competitors }\end{array}$ & 0.106 & 0.637 & 0.529 \\
$\begin{array}{l}\text { Relationship with } \\
\text { suppliers }\end{array}$ & 0.481 & 2.516 & $* 0.018$ \\
$\begin{array}{l}\text { Relationshipwith local } \\
\text { institutions }\end{array}$ & 0.163 & 0.910 & 0.371 \\
\hline
\end{tabular}

Note. Dependent variable $=$ performance; Statistical significance in terms of: ${ }^{*} \mathrm{p}<0.05$.

Thus, analyzing the Table 4 , it can be seen that relationship with competitors is not significant for the model $(\mathrm{p}>0.05)$, indicating that this relationship does not influence the performance of the companies surveyed, thus rejecting $\mathrm{H}_{1}$ (The cooperative relationships with competitors positively influence the performance of supermarket companies). This result contradicts the results obtained by other authors (e.g., Laimer \& Laimer, 2009), which have found that the cooperative relationships with companies in the same segment positively influence the performance.

The relationships with competitors or with other supermarket companies are related to carrying out purchases, promotions and employee training together and exchange information and knowledge between the owners of companies of the supermarket sector. Balestrin and Verschoore (2016) highlight three attributes that are needed for a cooperative relationship to get competitive gains. These attributes correspond to (1) the alignment of interests and objectives, (2) the interaction and (3) a form of coordination/ activities management. In this sense, it can be said that the joint activities and information exchange between companies, by itself, cannot result in competitive gains, such as improved performance.

When analyzing the results concerning the cooperative relationship with suppliers it is noted that this positively and significantly influences the performance of the companies surveyed, with $\mathrm{p}<0.05$ (Table 4). Thus the hypothesis $\mathrm{H}_{2}$ is confirmed (The cooperative relationships with suppliers positively influence the performance of supermarket companies).

Cooperative relationship with suppliers is related to joint activities like shopping, promotions, use of joint manpower, information exchange and also to decision on purchases and promotions. Thus, other studies (Chung \& Kim, 2003; Zeng et al., 2010) also showed the influence of cooperative relationships with suppliers in the companies' performance. Thus, one can infer that the relationship with suppliers influences the performance of companies surveyed, because it can provide joint productivity gains, risk reduction in developing products and services and assist in the adaptability of companies to the market (Zeng et al., 2010).

In this sense, Almeida and Vieira (2013) contribute exposing that collaboration between companies and their suppliers, as in the case of the companies surveyed, can bring benefits to agents involved, such as lower costs, improved service levels, reduced stocks, increased accuracy of purchase forecasts and operational flexibility. 
On the other hand, the relationship with local institutions presented $\mathrm{p}>0.05$ (Table 4) do not confirm hypothesis $\mathrm{H}_{3}$ (The cooperative relationships with local institutions positively influences the performance of supermarket companies). This result does not corroborate the findings of other studies that indicate that local institutions have an important role in improving the companies' competitiveness (Doloreux, 2004; Zeng et al., 2010).

To compare the evolution of the companies' performance associated with network and not associated to networks (Table 5) the chi-square test was carried out. The chi-square test is appropriate for testing hypotheses for verification of association between variables when the observations are about frequencies or counts. Therefore, the frequency responses are used at each end of the scale to verify the existence of differences between the companies associated with networks and companies not associated to networks.

Table 5

Performance evolution of associated companies and non-associated to networks

\begin{tabular}{lcc}
\hline Performance evolution & $\begin{array}{c}\text { Frequencies } \\
\text { Associated (n=13) }\end{array}$ & $\begin{array}{c}\text { Frequencies } \\
\text { Non-associated (n=18) }\end{array}$ \\
\hline Increased & $0.0 \%$ & $22.2 \%$ \\
Remain constant & $30.7 \%$ & $22.2 \%$ \\
Decreased & $69.3 \%$ & $55.6 \%$ \\
Total & $100.0 \%$ & $100.0 \%$ \\
\hline
\end{tabular}

Note. Chi-square Pearson's Coefficient: 3.333, $\mathrm{p}=0.189$.

According to the chi-square test carried out $(\mathrm{p}=0.189)$, there was no association between the evolution of the performance of the companies surveyed and participation in a cooperation network, rejecting thus the hypothesis $\mathrm{H}_{4}$ (Companies associated with networks have a better performance than the non-associated companies). This result contradicts the evidence by other studies (Balestrin \& Vargas, 2004; Wegner et al., 2006; Balestrin \& Verschoore, 2010), mentioning several competitive gains association of cooperation networks. On the other hand, these results corroborate the study of Gronum, Verreynne and Kastelle (2012), which have found that the cooperation networks do not influence the profitability and productivity growth of small and medium-sized Australian companies. So that the benefits of cooperative relationships can be unblocked, it is necessary to have other competitive gains, besides the financial performance, for example, the innovation results (Gronum et al., 2012).

Table 6 presents the results concerning the cooperative relationships of the companies associated with networks and companies non-associated to networks, assessed by the Student t-test. As it can be seen, the cooperative relationship with competitors and the relationship with suppliers were significantly higher $(\mathrm{p}<0.05)$ for companies associated with the networks, whereas the relationship with local institutions received no significant difference. In this sense, the hypothesis $\mathrm{H}_{5}$ is partly accepted (The cooperative relationships are larger in companies associated with a network). 
Table 6

Cooperative relationships of associated companies and non-associated to networks

\begin{tabular}{|c|c|c|c|c|}
\hline Cooperative relationship & $\begin{array}{c}\text { Mean } \pm \text { SD } \\
\text { Associated }(n=13)\end{array}$ & $\begin{array}{c}\text { Mean } \pm \text { SD } \\
\text { Non-associated }(n=18)\end{array}$ & Student's $\mathbf{t}^{*}$ & p value \\
\hline Relationship with competitors & $6.23 \pm 1.74^{\mathrm{a}}$ & $1,33 \pm 1.41^{b}$ & 10.104 & 0.001 \\
\hline Relationship with suppliers & $5.07 \pm 1.04^{\mathrm{a}}$ & $3,92 \pm 1.54^{b}$ & 2.330 & 0.030 \\
\hline Relationship with local institutions & $3.26 \pm 1.14^{\mathrm{a}}$ & $2,48 \pm 1.34^{\mathrm{a}}$ & 1.689 & 0.102 \\
\hline
\end{tabular}

Note. Different letters in the same line correspond to the significant difference in terms of: ${ }^{*} \mathrm{p}<0.05$.

The cooperative relationships with competitors, which involve joint activities and information and knowledge exchange are effectively larger and more formalized in companies participating networks. This result corroborates those found by Laimer and Laimer (2009), in which companies from the supermarket sector participating of networks obtained larger cooperation results and also showed to have greater discretion in joint activities (purchases and promotions) with competitors.

On the other hand, participation in a network did not influence the relationship between companies and local institutions, such as commercial associations, unions and government organizations. Moreover, it is observed that for the companies surveyed, network participants or not, the relationship with local institutions is very low, with levels of agreement with the minor affirmative framing (below the middle of the scale), which indicates disagreement with the affirmations (Table 6).

In this sense, some studies show that cooperation between local and government institutions are affected by factors such as the profile of the leadership of institutions, local political arenas and perception about the formation of cooperation networks between local governments and companies (Yanez, Magnier, \& Ramirez, 2008). Matt and Wolff (2004) state that the institutional logic of local governments, such as weaker or stronger political positions, can determine a stronger or weaker relationship with the companies. In another aspect, it may be that local institutions do not provide incentives or services for undertakings to draw a cooperative relationship. Among the incentives and services that could be made available are the financial support policies, strategic management programs, support innovation, educational services, providing economic information and marketing services (Balestrin \& Arbage, 2007; Zeng et al., 2010).

Finally, the relationship with suppliers was statistically higher for companies inserted in a network, accepting thus the $\mathrm{H}_{5 \mathrm{~b}}$ hypothesis. In this way, the relationship with suppliers in companies in the supermarket sector has already been shown in other studies, such as Vieira et al. (2009), which have found that collaboration in supermarket retail chain is influenced by interpersonal integration between the agents, by sharing costs and strategic integration.

Therefore, the participants' companies of a network may have a competitive advantage over those that do not participate because they have better relationships with suppliers, which according to the presented regression model (Table 4) positively influences the companies' performance. Moreover, the benefits of cooperative relationships may be greater the higher the level of cooperation between actors of the chain (Vieira et al., 2009). Finally, Table 7 shows a summary of results of the research hypothesis testing. 
Table 7

Summary of results of the research hypothesis testing

\begin{tabular}{lc}
\hline Hypothesis & Result \\
\hline $\mathrm{H}_{1}:$ The cooperative relationships with competitors positively influence the performance of supermarket companies. & Rejected \\
\hline $\mathrm{H}_{2}:$ The cooperative relationships with suppliers positively influence the performance of supermarket companies. & Accepted \\
\hline $\mathrm{H}_{3}:$ The cooperative relationships with local institutions positively influence the performance of supermarket & Rejected \\
\hline companies. & Rejected \\
\hline $\mathrm{H}_{4}:$ Companies associated with networks have a better performance than the non-associated companies. & Accepted \\
\hline $\mathrm{H}_{5 \mathrm{~b}}:$ The cooperative relationships with competitors are larger in companies associated with a network. & Accepted \\
\hline $\mathrm{H}_{5 \mathrm{c}}:$ The cooperative relationships with local institutions are higher in companies associated with a network. & Rejected
\end{tabular}

Thus, it can be observed that the hypotheses $\left(\mathrm{H}_{1}, \mathrm{H}_{2}\right.$ and $\left.\mathrm{H}_{3}\right)$ that verified the influence of cooperative relationships in the performance of companies, only the hypothesis $\mathrm{H}_{2}$ was accepted, thus demonstrating that only the relationship with suppliers has influence on performance of the companies surveyed. The other hypotheses $\mathrm{H}_{1}$ and $\mathrm{H}_{3}$, which refer to the relationship with competitors and with local institutions, were rejected. Whereas regarding hypotheses that evaluated the difference between cooperative relationships of the companies associated with networks and companies non-associated to networks $\left(\mathrm{H}_{5 \mathrm{a}}, \mathrm{H}_{5 \mathrm{~b}}\right.$ and $\left.\mathrm{H}_{5 \mathrm{c}}\right)$, observe that the $\mathrm{H}_{5 \mathrm{a}}$ and $\mathrm{H}_{5 \mathrm{~b}}$ hypotheses were accepted, i.e., the cooperative relationships with competitors and suppliers are higher in companies associated with the networks. Moreover, the hypothesis $\mathrm{H}_{4}$ was rejected, indicating no association between the evolution of the performance of the companies surveyed and participation in a cooperation network.

\section{Conclusion}

This study investigated the influence of cooperative relationships in the performance of companies in the supermarket sector. For the attainment of this objective, three types of cooperative relationships with competitors, with suppliers and with local institutions were analyzed. Thus, this study found that only the cooperative relationships with suppliers influence on company performance. Although other forms of cooperative relationships are widely discussed in the literature by generate competitive gains, only the relationship with suppliers was significant in the proposed regression model.

This result may be related to other factors that the literature discusses. In this sense, some authors (Balestrin \& Verschoore, 2016) show that for a cooperative relationship to provide competitive gains, it is necessary for companies to pursue common or coherent objectives, to have interaction and coordination mechanisms. Thus, the cooperative relationship with competitors and local institutions, characterized by joint activities and information and knowledge exchange did not impact the performance and competitiveness of the supermarket companies analyzed.

In addition, this study also compared the performance of supermarket companies associated and not associated to cooperation networks. The results show that there is no association between participation in a cooperation network, such as networks of supermarkets analyzed, and achievement of better performance. However, the supermarket companies associated with networks had better level of cooperative relationship with suppliers, which positively impacts on performance, and therefore have an advantage over the non-associated.

The theoretical and managerial contribution of the study is the realization of a 
quantitative research in one segment to seek to broaden the knowledge about the cooperative relationships and the impact of these in the companies' performance.

Among the research limitations the small number of respondent companies (31 companies) can be mentioned, suggesting to conduct of a research of greater proportions, so that the results can be generalized. Furthermore, research is suggested with the inclusion of variables such as level of interaction and pursuit of common goals, as well as other performance mediating variables indicated in the literature such as learning and innovation (Balestrin \& Verschoore, 2010; Gronum et al., 2012; Balestrin $\&$ Verschoore 2016), so that they can clarify how competitive gains can be achieved from cooperative relationships.

\section{References}

Ahuja, G. (2000). Collaboration networks, structural holes, and innovation: A longitudinal study. Administrative Science Quarterly, 45(3), 425-455.

Almeida, A. M. D. P., \& Vieira, J. G. V. (2013). Logística colaborativa: Um estudo com fornecedores de supermercados de pequeno e médio porte. Revista Gestáo Industrial, 9(3), 745-764.

Associação Brasileira de Supermercados. (2014). Estudo sobre redes de negócios. Recuperado de http://www.abras.com.br/economia-e-pesquisa/ pesquisas-sazonais/redes-de-negocios/

Balestrin, A., \& Arbage, A. P. (2007). A perspectiva dos custos de transação na formação de redes de cooperação. RAE-eletrônica, 6(1), 1-26. Recuperado de http://rae.fgv.br/sites/ rae.fgv.br/files/artigos/10.1590_S167656482007000100007.pdf

Balestrin, A., \& Vargas, L. M. (2004). A dimensão estratégica das redes horizontais de PMEs: Teorizações e evidências. Revista de Administração Contemporânea, 8(1), 203-228.
Balestrin, A., \& Verschoore, J. (2010). Aprendizagem e inovação no contexto das redes de cooperação entre pequenas e médias empresas. Revista Organizaçóes \& Sociedade, 17(53), 311-330.

Balestrin, A., \& Verschoore, J. (2016). Redes de cooperação empresarial: Estratégias de gestão na nova economia (2a ed.). Porto Alegre: Bookman.

Balestrin, A., Verschoore, J. R., \& Reyes, E., Jr. (2010). Campo de estudo sobre redes de cooperação interorganizacional no Brasil. Revista de Administração Contemporânea, 14(3), 458-477.

Barney, J. B. (1991). Firm resources and sustained competitive advantage. Journal of Management, 17(1), 99-120.

Bizzi, L., \& Langley, A. (2012). Studying processes in and around networks. Industrial Marketing Management, 41(2), 224-234.

Britto, J. (2002). Cooperação interindustrial e redes de empresas. In D. Kupfer, \& L. Hasenclever (Orgs.), Economia industrial: Fundamentos teóricos e práticos no Brasil (pp. 345-388). Rio de Janeiro: Elsevier.

Bueno, B., \& Balestrin, A. (2012). Inovação colaborativa: Uma abordagem aberta no desenvolvimento de novos produtos. Revista de Administração de Empresas, 52(5), 517-530.

Bulgacov, S., Arrebola, M. C., \& Gomel, M. M. (2012). Recursos compartilhados: Uma aplicação da visão baseada em recursos em um condomínio tecnológico no Paraná. Revista de Ciências da Administração, 14(32), 92-106.

Caldeira, A., Durão, D. H. V., Pizzol, F. R., Pizzol, H. R., \& Brasil, D. W. (2015). Estratégias de cooperação para a competitividade no setor têxtil brasileiro. Revista Alcance, 22(3), 333-348.

Castells, M. (1999). A sociedade em rede. São Paulo: Paz e Terra. 
Chung, S., \& Kim, G. M. (2003). Performance effects of partnership between manufacturers and suppliers for new product development: The supplier's standpoint. Research Policy, 32(4), 587-603.

Coutinho, L., \& Ferraz, J. C. (1994). Estudo da competitividade da indústria brasileira. Campinas: Papirus.

Cropper, S., Ebers, M., Huxham, C., \& Ring, P. S. (2008). Introduction. In S. Cropper, M. Ebers, C. Huxham, \& P. S. Ring (Orgs.), The oxford handbook of inter-organizational relations (pp. 3-21) Oxford: Oxford Press.

Dagnino, G. B., Levanti, G., \& Picone, A. M. (2015). Interorganizational network and innovation: A bibliometric study and proposed research agenda. Journal of Business \& Industrial Marketing, 30(3), 354-377.

Dalcol, C. C., Siluk, J. C. M., A. L. Neuenfeldt, A. L., Jr., \& Soliman, M. (2014). Mensuração da competitividade em instituiçôes de ensino superior privadas com base nas redes sociais digitais. Perspectivas em Gestão \& Conhecimento, 4(special), 96-108.

Doloreux, D. (2004). Regional networks of small and medium sized enterprises: Evidence from the metropolitan area of Ottawa in Canada. European Planning Studies, 12(2), 173-189.

Dyer, J. H., \& Singh, H. (1998). The relational view: Cooperative strategy and sources of interorganizational competitive advantage. Academy of Management Review, 23(4), 660-679.

Ebers, M. (1997). Explaining inter-organizational network formation. In M. Ebers (Ed.), The formation of interorganizational networks (pp. 3-40). Oxford: Oxford University Press.

Ferraz, J. C., Kupfer, D., \& Haguenauer, L. (1996). El desafio competitive para la industria brasileña. Revista de La Cepal, 58, 145-173.
Ferreira, I., Jr., \& Teixeira, R. M. (2008). Redes de pequenas empresas: A aplicação de uma tipologia em uma rede de supermercados. Revista de Administração Mackenzie, 8(3), 128-152.

Gaspar, M. A., Borgato, F., \& Lima, I. C. (2013). Estratégia de atuação em rede de negócios: Estudo de caso no pequeno varejo de alimentos. Revista da Micro e Pequena Empresa, 7(1), 3-16.

Gronum, S., Verreynne, M. L., \& Kastelle, T. (2012). The role of networks in Small and mediumd sized enterprise innovation firm performance. Journal of Small Business Management, 50(2), 257-282.

Gulati, R. (1999). Network location and learning: The influence of network resources and firm capabilities on alliance formation. Strategic Management Journal, 20(5), 397-420.

Haguenauer, L. (2012). Competitividade: Conceitos e medidas. Revista de Economia Contemporânea, 16(1), 146-176.

Hair, J. F., Jr., Babin, B., Money, A. H., \& Samouel, P. (2005). Fundamentos de métodos de pesquisa em administração. Porto Alegre: Bookman.

Hair, J. F., Jr., Black, W. C., Babin, B. J., Anderson, R. E., \& Tatham, R. L. (2009). Análise multivariada de dados (6a ed.). Porto Alegre: Bookman.

Heide, J. B., \& John, G. (1990). Alliances in industrial purchasing: The determinants of joint action in buyer supplier relationships. Journal of Marketing Research, 27(1), 24-36.

Hennart, J. (2008). Transaction costs perspectives on inter-organizational relations. In S. Cropper, M. Ebers, C. Huxham, \& P. S. Ring (Orgs.). The Oxford Handbook of Inter-Organizational Relations (pp. 305-330) Oxford: Oxford University Press.

Instituto Brasileiro de Geografia e Estatística (2015). Classificação nacional de atividades 
econômicas. Rio de Janeiro: Autor. Recuperado de http://www.cnae.ibge.gov.br

Kaplan, R. S., \& Norton, D. P. (1997). A estratégia em ação: Balanced scorecard (26a ed.) São Paulo: Elsevier.

Keupp, M. M., Palmié, M., \& Gassmann, O. (2012). The strategic management of innovation: A systematic review and paths for future research. International Journal of Management Reviews, 14(4), 367-390.

Laimer, C. G. (2007). Redes de empresas: Uma análise do desempenho empresarial. Revista Contemporânea de Ciências Sociais Aplicadas da FAPLAN, 4(6), 163-182.

Laimer, C. G. (2008). Construção de métricas para análise de redes de empresas [Working paper]. Faculdade Meridional (IMED), Escola de Administração, Passo Fundo, RS, Brasil.

Laimer, C. G., \& Laimer, V. R. (2009). Relaçôes de cooperação na perspectiva da visão baseada em recursos. Revista de Administração da Unimep, 7(3), 93-110.

Lee, J., Park, S. H., Ryu, Y., \& Baik, Y. S. A. (2010). Hidden cost of strategic alliances under Schumpeterian dynamics. Research Policy, 39(2), 229-238.

Lima, D. O., Fo., Maia, F. S., Sproesser, R. L., Moraes, F., \& Moraes, R. (2006). Redes de cooperação no varejo alimentar de vizinhança: Percepçôes dos associados. Gestão \& Produção, 13(2), 311-324.

Malhotra, N. (2012). Pesquisa de marketing: Uma orientação aplicada (6a ed.). Porto Alegre: Bookman.

Man, T. W. Y., Lau, T., \& Chan, K. F. (2002). The competitiveness of small and medium enterprises: A conceptualization with focus on entrepreneurial competencies. Journal of Business Venturing, 17(2), 123-142.
Marcon, C., \& Moinet, N. (2001). Estratégia-rede: Ensaio de estratégia. Caxias do Sul: Educs.

Matt, M., \& Wolff, S. (2004). Incentives, coordination and learning in governmentsponsored vs. spontaneous inter-firm research cooperation. International Journal of Technology Management, 27(8), 694-711.

Nieto, M. J., \& Santamaria, L. (2007). The importance of diverse collaborative networks for the novelty of product innovation. Technovation, 27(7), 367-377.

Olave, M. E. L., \& Amato, J., Neto. (2005). A formação de redes de cooperação e clusters em países emergentes: Uma alternativa para PMEs no Brasil. In J. Amato, Neto (Org.), Redes entre organizaçóes: Dominio do conhecimento e da eficácia operacional (pp. 68-93). São Paulo: Atlas.

Oliver, C. (1990). Determinants of interorganizational relationships: Integration and future directions. Academy of Management Review, 15(2), 241-265.

Porter, M. E. (1991). Estratégia competitiva: Técnicas para análise de indústrias e da concorrência (7a ed.) Rio de Janeiro: Elsevier.

Richardson, R. J. (1999). Pesquisa social: Métodos e técnicas (3a ed.). São Paulo: Atlas.

Santos, J. L. S., Kalsing, M., \& Hansen, P. B. (2014, outubro). Redes de cooperação interorganizacional: Uma análise sistemática da produção científica na Web of Science de 19812013. Anais do Seminário em Administração, São Paulo, SP, Brasil, 17. Recuperado de http:// semead6.tempsite.ws/17semead/resultado/ trabalhosPDF/1391.pdf

Vieira, J., Yoshizaki, H., \& Ho, L. (2009). Collaboration intensity in the Brazilian supermarket retail chain. Supply Chain Management, 14(1), 11-21.

Wegner, D., Agnes, J. I., Callado, A. L. C., \& Callado, A. A. C. (2016). Cooperar vale a pena? 
Uma análise comparativa do desempenho de empresas em rede, participantes de franquias e empresas individuais. Revista de Administração da Unimep, 14(1), 80-113.

Wegner, D., Wittmann, M. L., \& Dotto, D. M. R. (2006). Redes de empresas no Rio Grande do Sul: Uma análise de resultados competitivos e fatores de desenvolvimento. GESTÃO.Org Revista Eletrônica de Gestão Organizacional, 4(1), 74-90. Recuperado de http://www.revista.ufpe. br/gestaoorg/index.php/gestao/article/view/53

Yanez, C. J. N., Magnier, A., \& Ramirez, M. A. (2008). Local governance as government business cooperation in western democracies: Analysing local and intergovernmental effects by multi-level comparison. International Journal of Urban and Regional Research, 32(3), 531-547.

Zaccarelli, S. B. (2006). Estratégias e sucesso nas empresas. São Paulo: Saraiva.

Zeng, S. X., Xie, X. M., \& Tam, C. M. (2010). Relationship between cooperation networks and innovation performance of SMEs. Technovation, 30(3), 181-194.

Supporting Agencies: The author gratefully acknowledges financial support from the CAPES Foundation and the Meridional Foundation.

\section{Authors:}

1. Andressa Centenaro, MSc. in Management, Faculty Meridional (IMED), IMED Business School.

E-mail: centenaro.andressa@gmail.com

2. Claudionor Guedes Laimer, PhD. in Management, University of Vale do Rio dos Sinos - Unisinos, Brazil. E-mail: laimer@imed.edu.br

\section{Contribution of each author:}

\begin{tabular}{lcc}
\hline Contribution & $\begin{array}{c}\text { Andressa } \\
\text { Centenaro }\end{array}$ & $\begin{array}{c}\text { Claudionor Guedes } \\
\text { Laimer }\end{array}$ \\
\hline 1. Definition of research problem & $\sqrt{ }$ & $\sqrt{ }$ \\
2. Development of hypotheses or research questions (empirical studies) & $\sqrt{ }$ \\
3. Development of theoretical propositions (theoretical Work) & $\sqrt{ }$ \\
4. Theoretical foundation/ Literature review & $\sqrt{ }$ & $\sqrt{ }$ \\
5. Definition of methodological procedures & $\sqrt{ }$ \\
6. Data collection & $\sqrt{ }$ \\
7. Statistical analysis & $\sqrt{ }$ \\
8. Analysis and interpretation of data & $\sqrt{ }$ \\
9. Critical revision of the manuscript & $\sqrt{ }$ \\
10. Manuscript Writing & $\sqrt{ }$ & $\sqrt{ }$ \\
\end{tabular}

